\title{
The model of neoclusterization as a theoretical basis of innovative development of the agricultural sector of the Volga region
}

\author{
Dmitry Napolskikh ${ }^{1 *}$ \\ ${ }^{1}$ Volga State University of Technology, 424000, Yoshkar-Ola, Russia
}

\begin{abstract}
This article examines the contradictions and the characteristics of clustering and innovative development in the agricultural sector. The author's approach focused on the development of an integrated clustering model of the Volga Region economic space, considering clusters as the fundamental segments of the agricultural sector. The international experience in coordination of territorial and agricultural cluster development was taken into account, the characteristics of the implementation of the Russian cluster policy are attributed. A set of parameters were collected in order to be able to characterize different approaches to cluster policy, depending on the territorial or sectoral affiliation of the cluster. The general directions of improvement of the cluster policy of the Russian Federation within the framework of the neoclusterization model were taken into consideration.
\end{abstract}

\section{Introduction}

In modern conditions of development of the agricultural sector, cluster policy remains one of the most effective areas of state regulation [1], integrating the most effective tools for innovative development of territories and supporting high rates of economic growth [2]. The advantage of the agricultural clusters as a form of production organization is the possibility of flexible application of both market mechanisms of economic development and state support for the cluster [3]. The formation and development of the agricultural clusters is an important factor of territorial development, the institutional environment of the cluster contributes to the growth of labor productivity, the development of labor mobility of highly qualified personnel and the diffusion of innovations [4]. The main guidelines of cluster policy should be not only the development of regional investment projects in order to receive support from foreign investors, but also the active attraction of foreign enterprises from related sectors of the economy and services to the territory of the cluster [5]. In order to support the Russian economy and develop investment infrastructure, the strategy for innovative development of the Russian Federation provides for the formation of innovative territorial clusters $[6,7]$.

The theoretical and practical significance of the issues of assessing the innovative potential of the region as a factor of the effectiveness of the agricultural sector of the Volga region was the topic of this study.

\section{Methodology}

A set of parameters was formed that allows us to characterize different approaches to agricultural policy $[8,9]$, depending on the territorial or industry affiliation of the agricultural cluster. The main parameters of cluster development include:

- The number of key sectors of the agricultural cluster, which characterizes the mono - or multi-sectoral nature of cluster development;

- The level of concentration of cluster enterprises on the territory of the region, which allows us to assess the degree of involvement of the cluster in interregional cooperation;

- The number of cluster organizations and the weight of the "core" of the cluster in the number of employees, as well as in the revenue of the cluster;

- The stage of the cluster life cycle and the level of development of its institutional environment;

- The level of innovation of the cluster, characterized by the share of high-tech and high-tech products in the total volume.

\section{Results}

\subsection{International experience of cluster policy}

In the course of the study, various methodological approaches to the coordination of cluster and territorial development programs were considered, the presence of which indicates the specifics of the processes of

\footnotetext{
${ }^{*}$ Corresponding author: yal05@mail.ru
} 
clustering of the economy in different countries [10]. In 2020 cluster policy remains an important area of state regulation in developed countries such as USA, Canada, European Union, etc. Cluster policy of the United States of America was implemented in the framework of the National innovative development strategy, adopted in 2009. The main objectives of this strategy were the increase of the investment attractiveness of cluster initiatives in high-tech and knowledge-intensive sectors of production, to increase the global competitiveness of American industry through production and management innovations. Measures of state regulation of the formation and development of clusters are implemented both at the national level and at the level of individual state programs. The main directions of state support for the development of clusters in the United States are: creation of innovative and production infrastructure facilities; financing of R\&D of enterprises and organizations of the cluster; benefits for small and medium-sized innovative entrepreneurship; development of human capital of clusters [11]. The European Union currently implements 30 nationallevel cluster development programs covering $20 \mathrm{EU}$ member states, as well as 55 regional-level programs in 27 European regions. At the same time, the levels of implementation for different national models of cluster policy of the EU member states may differ: a number of states, in particular Germany and Poland, implement cluster development programs at the national, interregional and regional levels, while in most European countries cluster policy is implemented at the national and regional level. For the European Union, the cluster policy was updated by the large-scale goals of the Horizon 2020 program implemented since 2014, which integrates the EU's programs in the field of science and innovation. The priority areas of formation and support of cluster initiatives within the framework of this program are nanotechnologies, information technologies, technologies of rational use of natural resources and biotechnologies, and green energy. In total, 80 billion euros per year are planned to be spent on innovative development, including on the basis of cluster policy mechanisms, within the framework of the Horizon 2020 program [12]. Strategic plan development for 2016-2020 is focused on achieving in the year 2020 the following targets of economic development: growth of foreign trade turnover of the EU countries in \% of total EU GDP from $29 \%$ to $56 \%$ for goods and from $9 \%$ to $53 \%$ for services; the growth in the share of investment on R\&D as a percentage of total EU GDP from $2 \%$ to $3 \%$. We emphasize the complementarity of the conceptual foundations and tools of modern cluster policy aimed at the global competitiveness of clusters through the active introduction of innovative technologies to these goals [13]. One of the distinctive features of the Japanese model of cluster development is the priority of supporting small and medium-sized innovative enterprises, which are the basis of innovative "knowledge clusters" formed on the basis of leading universities [14]. In addition to innovation clusters, the Japanese model of cluster policy provides support for industrial clusters in more traditional sectors of the economy, which act as a point of growth for the economy of individual regions. It should be noted that other economically developed countries of Asia (South Korea, China, and Singapore) are characterized by a centralized approach to cluster development, in which the initiator and key participant of cluster projects are public authorities [15]. At the same time, when developing cluster development programs, a sectoral rather than a territorial approach is a priority. The territorial approach to cluster policy, based on the analysis of the resource potential of individual administrative-territorial units, is more typical for Latin American countries [16].

\section{2 innovative development of the agricultural sector of the Volga region}

By the beginning of the third decade of the XXI century, the scale of federal support for agricultural cluster initiatives in the regions of Russia has significantly decreased. Considering the dynamics of the implementation of programs for the formation of innovative and industrial clusters, we can conclude that the final decline of the "first wave" of clustering of the agricultural sector, which peaked in 2012-15. This trend is due to both the unfavorable macroeconomic environment and the lack of stability of the cluster development model in modern Russian conditions. The coronavirus pandemic and increased sanctions pressure against Russia have revealed a complex of implicit problems that have worsened against the background of a decline in oil and gas budget revenues. At the same time, the cluster model of agricultural sector development still demonstrates high performance in both economically developed and developing countries [17]. It should also be noted the successful experience of implementing cluster policy in a number of innovative regions of Russia. Approaches to adaptation and further updating of the cluster model of development in Russia have been formalized in a number of strategic and program documents of the federal level. Modernization of the agricultural sector and transition to an innovative model of economic development based on the formation of clusters were key priorities for the implementation of the Strategy of socio-economic Development of the Russian Federation until 2020. A serious barrier to the implementation of these strategic directions was the low susceptibility to innovation of the economic system of the Russian Federation. The Ministry of Economic Development of the Russian Federation is the key state authority that administers the formation and development of innovation clusters. In 2012, the Ministry launched the first comprehensive program for the formation and development of innovative territorial clusters, and in 2016, the Ministry initiated the project "Development of innovative clusters-leaders of worldclass investment attractiveness". We note the high cluster activity of the subjects of the Russian Federation that are part of the Volga Federal District. 
The most developed regions of the Volga region in terms of the formation and development of clusters are traditionally considered to be the Republics of Tatarstan and Bashkortostan, Perm Krai, Samara, Ulyanovsk and Penza regions. It should be noted a slowdown in activity on realization of cluster initiatives after 2014/15 as in Russia as a whole, and the regions of the Volga region (Fig. 1).

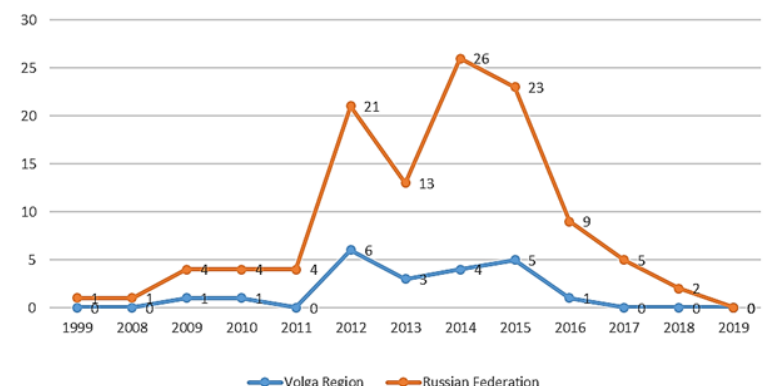

Fig. 1. The number of clusters formed in the Russian Federation and the Volga Federal District (Built by the author).

\subsection{The model of neoclusterization of the agricultural sector of the Volga region}

The institutional design of the agricultural policy over the past decade has undergone a number of conjunctural changes. Initially, Russian agricultural clusters were formed in the context of a nationwide vector of "modernization", which provides for technological renewal of production (the program for the development of innovative territorial clusters). Further, the vector of political conjuncture gradually shifted to "import substitution" (formation of the Register of industrial Clusters of the Russian Federation). The economic essence of these areas of state policy is the innovative transformation of the economy, which is the transition of Russian industry mainly to the fifth and sixth technological modes [18]. To date, the agricultural cluster remains the main model in the world economic science, which has the potential for a comprehensive solution to the above problems.

Innovation clusters are simultaneously aimed at creating new industries ("neoindustrialization"), technological renewal of existing industry complexes ("modernization") and the production of competitive products ("import substitution"). Thus, the analysis of the current results of cluster policy and its restart for regions developing cluster initiatives of the first wave and the generation of a new "second wave" of clustering, mainly in regions where there are no effectively functioning clusters ("neoclusterization"), remains highly relevant.

In this model of neoclusterization production, providing for the formation and development in the Russian regions agricultural clusters has a number of significant limitations and problems. The key constraint is the insufficient demand of the Russian agricultural sector for innovative technologies and high-tech products. An important problem is the insufficient level of development of institutional forms of production organization that can become growth points for new innovative agricultural clusters. The most complementary to the cluster model of innovative transformation of the economy, the federal project for the development of special economic zones (SEZ) was actually suspended, and the focus of its implementation was shifted to the sub-federal level. Technology platforms within the National Technology Initiative (NTI) have great potential, but the formation of new markets and technology platforms within the NTI is not sustainable and scalable today. At the same time, it is the integration within the cluster as a larger and more flexible system of other forms of spatial organization of production used in the Russian Federation (SEZ, NTI, etc.) that can bring them to the necessary level of efficiency due to synergetic effects.

A full-fledged innovative transformation of production at the level of Russian regions, many of which mainly remain at the level of the third and fourth technological orders, implies a change in the structure of the economic space and the system of production relationships. At the same time, the main barrier to giving the Russian economy a sustainable vector of innovative development is the insufficient level of development of the institutional environment and the connectivity of the economic space at the level of Russian regions. In this connection, an important factor in ensuring sustainable and predictable results of innovative transformation of the regional economy is to take into account the peculiarities of their institutional environment and the nature of the distribution of productive forces in the framework of cluster policy.

\section{Conclusion}

All of the above is a weighty justification for the relevance of our chosen research topic. The role of agricultural clusters as points of economic growth and increasing connectivity of the country's economic space remains relevant. In our opinion, the cluster model of development remains one of the few internal reserves for intensifying the processes of socioeconomic development at the sub-federal level. In this regard, the scientific task of searching for models of formation and development technologies of clusters that are relevant to modern conditions is actualized, due to the significant differentiation of sectoral and spatial conditions for the development of the Russian economy. The concept of an agricultural cluster and its corresponding methodological tools are proposed as a theoretical and methodological basis for optimizing innovation processes in the context of spatial development of the Russian Federation.

The above approaches to cluster development allow us to conclude that the cluster model of economic growth remains relevant, as well as the need to take into account national characteristics of the economy in the 
theoretical rethinking of the Russian clustering model. We note the need for a multi-level approach that allows us to identify the main shortcomings of the Russian clustering model implemented in the 2010s. The main disadvantages of the Russian cluster policy include the following phenomena identified during the analysis. First, it is a different level of capabilities of different subjects of the Russian Federation in relation to the task of lobbying for the region's participation in federal programs of innovative and cluster development. It should also be noted that there is insufficient coordination of goals and measures of state regulation due to the subordination of cluster development programs to two federal ministries: the Ministry of Economic Development of the Russian Federation and the Ministry of Industry and Trade of the Russian Federation. Also, various institutions of socioeconomic development formed at the level of federal regions and individual subjects of the federation often do not ensure the achievement of the declared goals. A general conclusion can be drawn about the persistence of institutional barriers that prevent the effective implementation of cluster initiatives and their scaling in most regions of the Russian Federation. At the same time, the formation of intersectoral clusters (agricultural multiclusters) united by a common innovation core is becoming more important for our country.

The importance of the cluster model of intersectoral integration based on the formation of multicluster formations is due to the fact that in most Russian regions there is no pronounced specialization of industry. At the same time, in many regions during the Soviet period, scientific and production complexes were formed, which together with scientific and educational institutions can be considered as the scientific and technological core of neoclusterization. At the same time, the intensification of interregional diffusion of innovation is a factor of qualitative transformation of the economic space. Questions of the influence of economic space factors on the innovative development of regions, increasing the connectivity of the economic space on the basis of "digital proximity", as well as the prerequisites for the formation of national and local "innovation space" remain of high relevance for economic theory and management practice.

This research was supported by Grant of Russian scientific Foundation No. 19-78-00056 "Cluster model of Volga region development in the conditions of innovative economy".

\section{References}

1. T.K. Abdullaeva, R.B. Gamidullaev \& G.S.S.V. Dokholyan, V.Z. Petrosyants \& A.M. Sadykov, Economics and entrepreneurship, 469-482 (2014)

2. C. Ketels, Competitiveness and Clusters: Implications for a New European Growth Strategy,
84.

Available

at:

http://www.foreurope.eu/fileadmin/documents/pdf/

3. Y. Polozhentseva, M. Klevtsova, Procedia Economics and Finance, 27, 529-537 (2015)

4. N.A. Prodanova, N.S. Plaskova, V.A. Dikikh, L.V. Sotnikova, L.K. Nikandrova \& G.A. Skachko, 7, 35-46 (2019)

5. G.I. Idziev, Regional problems of economic transformation, 41, 62-66 (2014)

6. M.E. Porter, C.H. Ketels, Cheltenham, Edward Elgar, 172-183 (2009)

7. Forecast of long-term socio-economic development of the Russian Federation for the period up to 2030. Ministry of economic development of the Russian Federation. Available at:

http://old.economy.gov.ru/minec/activity/sections/ macro/prognoz/doc20130325_06 (2013)

8. The concept of long-term socio-economic development of the Russian Federation until 2020. Ministry of economic development of the Russian Federation. Available at: http://www.edqu.ru/upload/iblock/d08/3.1.2009.14 .pdf. (2008)

9. L.M. Gokhberg and others. Rating of innovative development of subjects of the Russian Federation. Issue 6. National research. Higher school of Economics. Moscow. 264 (2020)

10. Regions of Russia. Socio-economic indicators. 2019: Statistical Digest. M.: Rosstat. 1402 (2019)

11. Cluster Policy in Europe - A brief survey of cluster programmes in 31 European countries. European Commission, Oxford Research. Available at: http://www.clusterobservatory.eu/system/modules/ com.gridnine.opencms.modules.eco/ (2008)

12. F. Belloc, Journal of Economic Surveys. 26, 835864 (2012)

13. European Cluster Observatory. (2020), Available at: http://www.clusterobservatory.eu/

14. C. Ketels, S. Protsiv, Center for Strategy and Competitiveness Stockholm School of Economics Publ (2016)

15. T.K. Abdullaeva, R.B. Gamidullaev \& G.S. Sultanov, Revista ESPACIOS, 40, 14 (2019) Available https://www.revistaespacios.com/a19v40n16/1940 1614.html

16. R. Prodani, J. Bushati \& A. Andersons, Insights into Regional Development, 1, 333-342 (2019)

17. International Benchmarking Study of Competitiveness Poles and Clusters and Identification of Best Practices, (2012), Available at:

http://www.vegepolys.eu/media/international_benc hmarking_study_inovisa_pic_2012_092299500_1 147_26062012.pdf

18. Yu.V. Maksimov, Bulletin of the Lobachevsky University of Nizhny Novgorod. Series: Social Sciences, 36, 57-61 (2014)

19. E.M. Akhmetshin, Journal of Advanced Research in Law and Economics, 8, 1684-1692 (2017) 